\title{
THE IMPACT OF THE PSYCHOLOGICAL MARKETING FACTORS (TRICKS) ON CONSUMER'S BUYING DECISIONS
}

\author{
Davor Širola, PhD, College professor \\ Polytechnic of Rijeka \\ 58 Vukovarska street, 51000 Rijeka \\ e-mail: davor.sirola@veleri.hr \\ Martina Sudac, Profess. spec. oec. \\ Polytechnic of Rijeka \\ 58 Vukovarska street, 51000 Rijeka \\ e-mail: msudac@veleri.hr
}

\begin{abstract}
Psychology has an essential role in consumer behaviour comprehension and shaping of the appropriate marketing activities, especially in advertising, sales promotion and brand loyalty building. Applying distinct psychological marketing factors (tricks) has had a long history in traditional and even online retail commerce. Their impact on consumer buying decisions has been researched for decades (since the 1970s). However, consumers in Croatia have been able to experience these factors since the 1990s. The survey in this study collected data about the influence of prices, advertising, sales promotion, retail atmosphere, and packaging from 256 respondents. The analysis pointed out that only 9 (out of 26) researched psychology marketing tricks positively influence consumer buying decisions. Low prices and discounts were evaluated as the most critical factors (tricks), followed by a pleasant store ambience, music, and memorable promotional jingles respectively. Celebrity endorsement and appealing to scarcity were considered the least important factors. The research determined that younger consumers (aged below 30), women, students and respondents with higher family income are more prone to being triggered by the psychology marketing tricks.
\end{abstract}

Keywords: consumer behaviour, psychology marketing factors (tricks), buying decisions 


\section{INTRODUCTION}

The involvement of psychology principles within the consumer behaviour field has had a long history of descriptive and empirical research. According to Schumann et al. $(2008,3)$, it goes back to 1895, as applied psychology, but consumer psychology was not labelled until 1955. The foundation of the modern marketing research of customer segmentation and appropriate marketing stimuli (tricks) emanated from the seminal work of Jerry Yoram Wind and Richard Cardozo, published in 1974 (Booker, 2020).

Nowadays, psychology marketing factors (tricks) have become thoroughly researched and have been customary within numerous handbooks and guides for practitioners in retail commerce and, in recent years, in e-commerce as well (e.g. Samson, 2020, or Crobox, 2021). However, most studies explored the impacts of groups of stimuli, like pricing, incentives, communication or branding by employing different measurement scales (e.g. meta-analysis by Blut et al., 2018, 115, 122), but not the effects of individual marketing tricks within these groups.

The purpose of this study was to evaluate the acceptance of some well-known psychology marketing factors from different groups, without applying the focused measurement scales. This approach has allowed the investigated marketing tricks to be adapted to the Croatian context, as the most prominent national retailers use them.

\section{THEORETICAL AND CONCEPTUAL FRAMEWORK}

Consumer behaviour is considered a multidisciplinary science comprised of applied psychology, economy, sociology and marketing (Grbac, Lončarić, 2010, 17). It involves experimental, clinical and social psychology, micro and macroeconomics, demography, cultural anthropology, and more (Solomon et al., 2013, 25). The impact of the web and social media highlighted the new digital consumer and the need to update the consumer behaviour as a study of how individuals, groups, and organizations select, buy, use, and dispose of goods, services, ideas, or experiences to satisfy their needs and wants (Kotler, Keller, 2012, 151). The new digital world further enhanced the role of psychology in marketing and the influence of cultural, social and personal factors on consumer buying decisions. Hence, the latest, expanded edition of the well-known Cialdini book on the psychology of persuasion (2021) includes the analysis of digital imprint on seven principles of persuasion. These principles (and Cialdini's opus) are considered ones of the most influential in consumer behaviour and the marketing field. Cialdini's principles of reciprocation, liking, social proof, authority, scarcity, commitment/ consistency, and unity, or Thaler's endowment effect, mental accounting and nudging (crobox.com) stay behind the various marketing tricks intended to trigger the purchase intentions. Purchase intentions are regarded as a valuable predictor of actual behaviour (sales). For instance, a metaanalysis of Armitage and Conner $(2001,486)$ found the medium correlation level between intentions and behaviour $(r=0.47$ at $p<0.001)$. 
Most of the mentioned principles and effects are embedded in well-known consumer behaviour models as consumer characteristics or external social, cultural and situational factors. Some of the most recognizable models include the Engel, Kollat and Blackwell (EKB) model, Howard-Sheth model, Kotler's behavioural choice model ("Black box"), Nicosia or Alport Socio-Psychoanalytic model (more detailed in Goodhope, 2013, 166-170). Most of these models include a purchase intention and purchase as a final behavioural outcome.

This study investigates 26 prominent marketing factors (tricks) and their influence on the purchase intention (embedded within every statement). These factors pertain to the hedonic and utilitarian shopping context (Blut et al., 2018, 118). The extrinsic motives for hedonic, experiential shoppers comprehend low prices, discounts, coupons, and other incentives. Intrinsic motives (for utilitarian, functional shoppers) involve the in-store atmosphere, jingles, colours, celebrity endorsements, etc. Both groups of factors were successfully tested in diverse relations. E.g. the meta-analysis of Barari et al. $(2020,469)$, which encompassed 196 studies, established a positive impact of experiential and functional marketing factors on perceived value, behavioural and attitudinal engagement. The positive influence of different marketing stimuli (e.g. price, communication, store ambience, merchandise) on impulse buying, were found in Gopalkrishnan et al. $(2020,392)$ meta-analysis.

Marketing factors examined in this study include various discounts ( 6 statements), store ambience (5), price, scarcity and colours ( 2 items each), authority, loss aversion and other factors. Some of the statements were associated with Croatian products, companies or campaigns, including visual aids. Two hypotheses were tested:

$\mathrm{H}_{1}$ The influence and acceptance of psychological marketing tricks differ significantly depending on the respondents' demographics;

$\mathrm{H}_{2}$ Psychological marketing tricks positively influence consumer buying decisions.

\section{METHODOLOGY AND SAMPLE}

The empirical research was conducted via a questionnaire with 31 items prepared within the Google Forms tool (which allows diverse visual insertions). All variables were measured with a 5-point Likert-type scale where one means strongly disagree, and five mean strongly agree (except five demographic questions). The survey explored the attitudes and opinions of the convenience sample (mainly the younger, full-time and elder, parttime students in Croatia). In May 2021, 256 valid responses were collected. Table 1 comprises the demographic characteristics of the sample. 
Table 1. Sample characteristics

\begin{tabular}{|l|c|c|c|c|c|}
\hline Characteristics & No. & $\%$ & Characteristics & No. & Age \\
\hline Sex & 256 & & $<20$ & 21 & 8.2 \\
\hline Female & 203 & 79.3 & $21-30$ & 105 & 41 \\
\hline Male & 53 & 20.7 & $31-40$ & 39 & 15.2 \\
\hline Status: & 256 & & $41-50$ & 35 & 13.7 \\
\hline Pupils/students & 52 & 20.3 & $>51$ & 56 & 21.9 \\
\hline Employed & 179 & 69.9 & & 256 & 9 \\
\hline Unemployed (and other) & 25 & 9.8 & & 3.5 \\
\hline Household income over the last three years: & & 57 & 22.3 \\
\hline Below average (hardly making ends meet) & & 135 & 52.7 \\
\hline Average (enough for daily purposes and some savings) & 55 & 21.5 \\
\hline
\end{tabular}

Source: Author's research

The data were analyzed with JASP Statistical Analysis Software. The internal consistency of the instrument was verified using Cronbach alpha (Table 2).

Table 2. Cronbach alpha coefficient values

\begin{tabular}{|l|c|c|}
\hline Variable (concept) & No. of items & Cronbach coefficient \\
\hline Psychological marketing factors (tricks) & 26 & 0.88 \\
\hline
\end{tabular}

Source: Author's research

The analysis confirmed that Cronbach alpha is within the referential limits of reliability.

\section{RESEARCH FINDINGS}

The verification of the first hypothesis included conduction a t-test for independent samples and ANOVA. Table 3 contains the statistically significant differences for the investigated psychological marketing factors. 
Table 3. Differences regarding demographic features

\begin{tabular}{|c|c|c|c|c|c|c|}
\hline Sex & \multicolumn{2}{|c|}{$\begin{array}{l}\text { Female } \\
(n=203)\end{array}$} & \multicolumn{2}{|c|}{$\begin{array}{l}\text { Male } \\
(n=53)\end{array}$} & \multirow[t]{2}{*}{$t$} & \multirow[t]{2}{*}{ Sig. } \\
\hline Variable (statement) & A.M. & S.D. & A.M. & S.D. & & \\
\hline $\begin{array}{l}\text { When I notice a social media post on discounts in a } \\
\text { certain store, I usually check if there is something } \\
\text { for me. }\end{array}$ & 3.44 & 1.24 & 3.02 & 1.31 & 2.20 & $0.029 *$ \\
\hline When I'm in a store, I lose the sense of time. & 3.24 & 1.37 & 2.64 & 1.06 & 2.95 & $0.003^{* *}$ \\
\hline I often buy guided by instinct. & 3.44 & 1.14 & 3.04 & 1.13 & 2.29 & $0.023^{*}$ \\
\hline I consider e-commerce as more price-sensitive. & 2.97 & 1.25 & 3.58 & 1.23 & -3.20 & $0.002^{* *}$ \\
\hline Age & \multicolumn{2}{|c|}{$\begin{array}{l}\leq 30 \text { years } \\
(n=126)\end{array}$} & \multicolumn{2}{|c|}{$\begin{array}{l}\geq 31 \text { years } \\
(n=130)\end{array}$} & \multirow[t]{2}{*}{$t$} & \multirow[t]{2}{*}{ Sig. } \\
\hline Variable (statement) & A.M. & S.D. & A.M. & S.D. & & \\
\hline $\begin{array}{l}\text { When I spot discounts in stores, I instantly start } \\
\text { buying. }\end{array}$ & 3.36 & 1.27 & 2.58 & 1.08 & 5.28 & $0.000 * *$ \\
\hline $\begin{array}{l}\text { I buy products on discount sales, regardless of } \\
\text { whether I need them. }\end{array}$ & 2.44 & 1.24 & 1.92 & 1.13 & 3.47 & $0.001^{* *}$ \\
\hline
\end{tabular}

Notes: A.M. = arithmetic mean; S.D. = standard deviation; Sig. = significance; $* *$ significance level at 0.01 ; *significance level at 0.05

Source: Author's research

Table 3. (continued)

\begin{tabular}{|c|c|c|c|c|c|c|}
\hline \multirow{2}{*}{$\begin{array}{l}\text { Age } \\
\text { Variable (statement) }\end{array}$} & \multicolumn{2}{|c|}{$\begin{array}{l}\leq 30 \text { years } \\
(\mathrm{n}=126)\end{array}$} & \multicolumn{2}{|c|}{$\begin{array}{l}\geq 31 \text { years } \\
(n=130)\end{array}$} & \multirow{2}{*}{$t$} & \multirow{2}{*}{ Sig. } \\
\hline & A.M. & S.D. & A.M. & S.D. & & \\
\hline $\begin{array}{l}\text { Signs like: Crazy sales! Large discounts! Buy now! } \\
\text { Last day! lure me into shopping. }\end{array}$ & 3.11 & 1.36 & 2.26 & 1.27 & 5.15 & $0.000 * *$ \\
\hline $\begin{array}{l}\text { I'm prone to overbuy products or buy products } \\
\text { I don't need. }\end{array}$ & 2.62 & 1.32 & 2.05 & 1.12 & 3.75 & $0.000^{* *}$ \\
\hline $\begin{array}{l}\text { When I see the sign 'while stocks last', I'm afraid } \\
\text { I will lose the opportunity. }\end{array}$ & 2.02 & 1.19 & 1.71 & 0.97 & 2.34 & $0.020 *$ \\
\hline $\begin{array}{l}\text { When I see a celebrity endorsing a product or a } \\
\text { service, I get a desire to buy that product or service. }\end{array}$ & 1.85 & 1.09 & 1.60 & 0.91 & 1.99 & $0.048^{*}$ \\
\hline $\begin{array}{l}\text { Sometimes I wish for some food or want to try } \\
\text { some clothes because I've just seen a commercial } \\
\text { for that product. }\end{array}$ & 3.22 & 1.21 & 2.63 & 1.27 & 3.82 & $0.000 * *$ \\
\hline $\begin{array}{l}\text { When I notice a social media post on discounts in a } \\
\text { certain store, I usually check if there is something } \\
\text { for me. }\end{array}$ & 3.60 & 1.15 & 3.12 & 1.32 & 3.14 & $0.002^{* *}$ \\
\hline $\begin{array}{l}\text { Do you relate the colour black with a luxury brand } \\
\text { of a high-quality reputation? }\end{array}$ & 2.94 & 1.35 & 2.43 & 1.24 & 3.11 & $0.002^{* *}$ \\
\hline $\begin{array}{l}\text { An appealing store ambience inspires my desire for } \\
\text { shopping. }\end{array}$ & 3.63 & 1.14 & 3.32 & 1.08 & 2.24 & $0.026 *$ \\
\hline When I'm in a store, I lose track of time. & 3.36 & 1.35 & 2.88 & 1.26 & 2.94 & $0.004^{* *}$ \\
\hline When I enter my favourite store, I get euphoric. & 3.26 & 1.30 & 2.47 & 1.30 & 4.88 & $0.000 * *$ \\
\hline
\end{tabular}




\begin{tabular}{|c|c|c|c|c|c|c|}
\hline Some products completely grab my attention. & 3.63 & 1.30 & 3.08 & 1.27 & 3.38 & $0.001^{* *}$ \\
\hline I like to buy things considered as prestigious. & 2.25 & 1.24 & 1.82 & 1.02 & 3.04 & $0.003^{* *}$ \\
\hline I consider e-commerce as more price-sensitive. & 3.39 & 1.21 & 2.82 & 1.26 & 3.70 & $0.000^{* *}$ \\
\hline Family income & \multicolumn{2}{|c|}{$\begin{array}{l}\text { Below- } \\
\text { average and } \\
\text { sufficient } \\
(n=66)\end{array}$} & \multicolumn{2}{|c|}{$\begin{array}{l}\text { Average } \\
\text { and above- } \\
\text { average } \\
(n=190)\end{array}$} & \multirow[t]{2}{*}{$t$} & \multirow[t]{2}{*}{ Sig. } \\
\hline Variable (statement) & A.M. & S.D. & A.M. & S.D. & & \\
\hline $\begin{array}{l}\text { When I spot discounts in stores, I instantly start } \\
\text { buying. }\end{array}$ & 2.68 & 1.15 & 3.06 & 1.26 & -2.13 & $0.034^{*}$ \\
\hline $\begin{array}{l}\text { When I see the sign 'while stocks last', I'm afraid I } \\
\text { will lose the opportunity. }\end{array}$ & 1.64 & 0.92 & 1.94 & 1.14 & -1.97 & $0.050^{*}$ \\
\hline $\begin{array}{l}\text { An appealing store ambience inspires my desire for } \\
\text { shopping. }\end{array}$ & 3.23 & 1.06 & 3.55 & 1.13 & -2.05 & $0.042^{*}$ \\
\hline Place of residence & \multicolumn{2}{|c|}{$\begin{array}{l}\text { Primorje- } \\
\text { Gorski Kotar } \\
\text { County } \\
(n=196)\end{array}$} & \multicolumn{2}{|c|}{$\begin{array}{l}\text { Other } \\
\text { counties } \\
(n=60)\end{array}$} & \multirow[t]{2}{*}{$t$} & \multirow[t]{2}{*}{ Sig. } \\
\hline Variable (statement) & A.M. & S.D. & A.M. & S.D. & & \\
\hline $\begin{array}{l}\text { Sometimes I wish for some food or try some cloth } \\
\text { because I just saw a commercial for that product. }\end{array}$ & 2.83 & 1.30 & 3.22 & 1.14 & -2.07 & $0.040^{*}$ \\
\hline $\begin{array}{l}\text { When I like some overpriced product, I wait for } \\
\text { discounts and then buy it. }\end{array}$ & 3.62 & 1.19 & 4.00 & 1.12 & -2.20 & $0.029 *$ \\
\hline
\end{tabular}

Notes: A.M. = arithmetic mean; S.D. = standard deviation; Sig. = significance; ${ }^{* *}$ significance level at $0.01 ;$

*significance level at 0.05

Source: Author's research

Table 3. (continued)

\begin{tabular}{|l|c|c|c|c|c|c|c|c|}
\hline Status & \multicolumn{2}{|c|}{$\begin{array}{c}\text { Pupils/ } \\
\text { students } \\
\text { (n=52) }\end{array}$} & \multicolumn{2}{|c|}{$\begin{array}{c}\text { Employed } \\
\text { (n= 179) }\end{array}$} & \multicolumn{2}{|c|}{$\begin{array}{c}\text { Unemployed } \\
\text { and others } \\
\text { (n= 25) }\end{array}$} & F & Sig. \\
\hline Variable (statement) & A.M. & S.D. & A.M. & S.D. & A.M. & S.D. & & \\
\hline $\begin{array}{l}\text { Sometimes I wish for some food or want } \\
\text { to try some clothes because I've just seen } \\
\text { a commercial for that product. }\end{array}$ & 3.38 & 1.19 & 2.85 & 1.30 & 2.48 & 1.00 & 5.43 & $0.005^{* *}$ \\
\hline I can recall products by their jingles. & 3.94 & 1.11 & 3.49 & 1.28 & 2.80 & 1.26 & 7.23 & $0.001^{* *}$ \\
\hline $\begin{array}{l}\text { Some colours of the product or its } \\
\text { packaging play an important role in my } \\
\text { buying decision process. }\end{array}$ & 3.17 & 1.26 & 2.91 & 1.30 & 2.08 & 1.15 & 6.34 & $0.002^{* *}$ \\
\hline $\begin{array}{l}\text { I frequently leaf through the commercial } \\
\text { catalogues (leaflets) to find discounted } \\
\text { products. }\end{array}$ & 2.87 & 1.53 & 2.83 & 1.34 & 3.56 & 1.36 & 3.07 & $0.048^{*}$ \\
\hline
\end{tabular}

Notes: A.M. = arithmetic mean; S.D. = standard deviation; Sig. = significance; ${ }^{* *}$ significance level at 0.01 ; *significance level at 0.05

Source: Author's research 
The results indicate that the responses vary significantly depending on demographics. Predominantly younger respondents (below 30 years) tend to accept psychological marketing factors (15 out of 26) more than the older generations. These results suggest that more experienced consumers become resilient to most of the marketing tricks over time. Statistically, significant differences were found regarding all the other control variables (sex, family income, status and place of residence) but only for 2-4 marketing factors. These cases indicate that mainly women, pupils/ students and respondents with higher family income tend to be more prone to these marketing tricks. These results confirmed the differences depending on demographics, as hypothesized in $\mathbf{H}_{1}$, especially regarding the age of respondents. Table 4 contains the best (with mean values above 3 , considered neutral value on the scale from 1 to 5 ), and worst evaluated psychological marketing factors (mean values below 2).

Table 4. The most and the least influential psychological marketing factors

\begin{tabular}{|l|c|c|}
\hline Variable (statement) & A.M. & S.D. \\
\hline The price level has an essential role in my buying decision process. & 4.02 & 1.00 \\
\hline When I like an overpriced product, I wait for discounts and buy it then. & 3.71 & 1.18 \\
\hline Pleasant music relaxes me during shopping. & 3.55 & 1.20 \\
\hline I can recall products by their jingles. & 3.52 & 1.27 \\
\hline An appealing store ambience inspires my desire for shopping. & 3.47 & 1.12 \\
\hline I often buy guided by instinct. & 3.36 & 1.14 \\
\hline $\begin{array}{l}\text { When I notice a social media post about discounts in a certain store, I generally check } \\
\text { if there is something for me. }\end{array}$ & 3.36 & 1.26 \\
\hline Some products completely grab my attention. & 3.35 & 1.31 \\
\hline I consider e-commerce as more price-sensitive. & 3.10 & 1.27 \\
\hline When I see the sign 'while stocks last', I'm afraid I will lose the opportunity. & 1.86 & 1.09 \\
\hline $\begin{array}{l}\text { When I see a celebrity endorsing a product or service, I get a desire to buy that } \\
\text { product or service. }\end{array}$ & 1.72 & 1.01 \\
\hline
\end{tabular}

Notes: A.M. = arithmetic mean; S.D. = standard deviation

Source: Author's research

The results in table 4 indicate that around one third (9 out of 26) of investigated psychological marketing factors were evaluated as influential or acceptable (the results above the neutral value of three). Consequently, just over $1 / 3$ of the psychological marketing tricks work, i.e. impacts the respondents buying intentions and, finally, their buying decisions. Hence, the second hypothesis $\left(\mathrm{H}_{2}\right)$ was partially supported.

\section{DISCUSSION}

The psychological marketing factors (tricks) investigated in this study were primarily tested with recent examples from the Croatian FMCG (Fast-Moving Consumer Goods) industry. Therefore, these factors are being applied in practice and presumably positively influence sales figures and/ or brand loyalty. However, this study confirmed that only onethird of the tricks have an impact on respondents buying decisions. Other mean results remained below the value of 3 , which is considered a neutral response. Furthermore, 
younger consumers (below the age of 30 ) have a higher propensity to accept these tricks than the older ones. The experience and even memories of the pre-free market age in Croatia are possibly responsible for a more cautious approach among older generations.

Although the words 'trick', 'trigger' or similar weren't used within the questionnaire, the respondents had a good sense of the topic investigated. Hence, the respondents' bias toward socially desirable responses (i.e. accepting the psychological marketing tricks) could be an issue in this research. More bias among younger, female and less educated respondents in this study aligns with the results of the validation study on determinants of response behaviour in social sciences surveys by Preisendörfer \& Wolter (2014, cited in Bogner \& Landrock, 2016, 2). Resolving this issue has limited options. Kemper et al. (2012, 26) offered a short six-item scale to measure social desirability in social science surveys to control the confounding data. The other option implies neuromarketing research, which is effective, but too expensive for broader application. For instance, the FMRI usage revealed socially desirable answers from the participants in the study of effects on smoking behaviour caused by adding pictorial warnings to the cigarette packs (Lindstrom, 2012, 24).

Besides the issue of social desirability, there is a lack of studies comparable to the results of this research. Other studies applied a more focused approach. For instance, Buckley $(2020,17)$ meta-analyzed the effect of price, information and other incentives (nudges) on electricity consumption, i.e. the specific industry, while Gopalkrishnan et al. (2020, 392) meta-analyzed diverse marketing stimuli influence on impulse buying. Another perspective includes testing the impact of psychological marketing factors on actual case studies. E.g. Muchardie et al. $(2017,95)$ compared the influence of in-store promotion, store atmosphere, convenience, and merchandise against patronage intention, within two major convenience store businesses in Indonesia.

\section{CONCLUDING REMARKS}

The majority of psychology marketing factors are well anchored in verified psychology principles (like Cialdini's or Thaler's) and well proven within a practical industry application, and therefore are broadly accepted as marketing tools (e.g. Wintermeier, 2019). However, the lack of publicly available studies limits the Croatian marketers outside the large retailers (who presumably conduct their own investigations) to international sources. This study offers an introduction to more cognitions about the marketing tricks within the domestic context, notably for small entrepreneurs.

As discussed above, the differences between the low acceptance of analyzed psychology marketing factors in this research and their broad usage in practice might emerge from social desirability issues. Besides introducing suggested measures of social desirability question, future analysis of the topic should be more aligned with recognized psychology principles to provide a better insight into the influence of marketing factors with a proven psychology background on buying decisions.

Furthermore, future research should consider pretesting the scale to secure more content validity (clarity, unambiguity, comprehension), despite this research's satisfying level of reliability test. Moreover, accentuating the specific retail industry (for instance, fashion) might give more focused answers from the respondents. 


\title{
UTJECAJ PSIHOLOŠKIH MARKETINŠKIH FAKTORA (TRIKOVA) NA KUPOVNE ODLUKE POTROŠAČA
}

\author{
Dr. sc. Davor Širola, prof. v.š. \\ Veleučilište u Rijeci \\ Vukovarska 58, 51000 Rijeka \\ e-mail: davor.sirola@veleri.hr \\ Martina Sudac, struč. spec. oec. \\ Veleučilište u Rijeci \\ Vukovarska 58, 51000 Rijeka \\ e-mail: msudac@veleri.hr
}

\section{SAŽETAK}

Psihologija ima važnu ulogu u razumijevanju ponašanja potrošača $i$ oblikovanju odgovarajućih marketinških aktivnosti, posebno u oglašavanju, unapređenju prodaje $i$ stvaranju lojalnosti. Primjena raznih psiholoških marketinških čimbenika (trikova) ima dugu povijest u tradicionalnoj, pa i internet maloprodaji. Njihov utjecaj na kupovne odluke potrošača se istražuje još od 1970-ih. Potrošači u Hrvatskoj su tim čimbenicima izloženi od 1990-ih. Anketnim ispitivanjem prikupljeni su podaci o utjecaju cijena, oglašavanja, unapređenja prodaje, maloprodajne atmosfere i pakiranja od 256 ispitanika. Analiza je pokazala da samo devet (od ukupno 26) istraživanih psiholoških marketinških trikova pozitivno utječe na donošenje kupovnih odluka potrošača. Povoljne cijene i popusti su ocijenjeni kao najvažniji čimbenici koji utječu na kupovne odluke. Slijede ugodan maloprodajni ugođaj i glazba te pamtljivi promotivni jinglovi. Podrška (pokroviteljstvo) slavnih osoba i promoviranje oskudice zaliha prepoznati su kao najmanje važni čimbenici. Istraživanjem je utvrđeno da su mlađi ispitanici (ispod 30 godina), žene, studenti i ispitanici $s$ višim obiteljskim dohocima skloniji prihvaćanju psiholoških marketinških faktora.

Ključne riječi: ponašanje potrošača, psihološki marketinški čimbenici (trikovi), kupovne odluke 


\section{LITERATURE}

1. Armitage, C.J. and Conner, M. (2001). Efficacy of the Theory of Planned Behaviour: A metaanalytic review, British Journal of Social Psychology, Vol. 40, p. 471-499, DOI: 10.1348/ 014466601164939

2. Barari, M., Ross, M., Thaichon, S. and Surachartkumtonkun, J. (2021). A meta-analysis of customer engagement behaviour, International Journal of Consumer Studies, Vol. 45, Issue 4, p. 457477, https://doi.org/10.1111/ijcs.12609

3. Blut, M., Teller, C. and Floh, A. (2018). Testing Retail Marketing-Mix Effects on Patronage: A Meta-Analysis, Journal of Retailing, Vol. 94, Issue 2, p. 113-135, https://doi.org/10.1016/j. jretai.2018.03.001

4. Bogner, K. and Landrock, U. (2016). Response Biases in Standardized Surveys. GESIS Survey Guidelines, Mannheim, Germany: GESIS - Leibniz Institute for the Social Sciences, doi: 10.15465/gesis-sg_en_016

5. Booker, B. (2020). The 100-year history of market research - 1920 to 2020, https://www. askattest.com/blog/articles/history-of-market-research

6. Buckley, P. (2020). Prices, information and nudges for residential electricity conservation: A meta-analysis, Ecological Economics, Vol. 172, Issue 5, doi:10.1016/j.ecolecon.2020.106635

7. Cialdini, R.B. (2021). Influence, New and Expanded: the psychology of persuasion, Harper Business, New York

8. Gopalkrishnan, R., lyer \& Markus Blut, Hong Xiao, S. and Grewal. D. (2020). Impulse buying: a meta-analytic review, Journal of the Academy of Marketing Science, Vol. 48, p. 384-404, https://doi.org/10.1007/s11747-019-00670-w

9. Goodhope, O.O. (2013). Major Classic Consumer Buying Behaviour Models: Implications for Marketing Decision-Making, Journal of Economics and Sustainable Development, Vol.4, No.4, p. $164-172$

10. Grbac. B. and Lončarić. D. (2010). Ponašanje potrošača na tržištu krajnje i poslovne potrošnje, Sveučilište u Rijeci, Ekonomski fakultet, Rijeka

11. Kemper, C. J., Beierlein, C., Bensch, D., Kovaleva, A. and Rammstedt, B. (2012). Eine Kurzskala zur Erfassung des Gamma-Faktors sozial erwünschten Antwortverhaltens, Die Kurzskala Soziale Erwünschtheit-Gamma (KSE-G). GESIS-Working Papers, No. 2012/25. Cologne: GESIS Leibniz Institute for the Social Sciences.

12. Kotler, P. and Keller, K.L. (2012). Marketing Management, $14^{\text {th }}$ Edition, Prentice Hall, New Jersey

13. Lindstrom, M. (2012). Kupologija, Istine i laži o tome zašto kupujemo, Profil Knjiga, Zagreb

14. Muchardie, B. G., Yosa, F. and Gunawan, A. (2017). Comparative Study of Store Image, Patronage Intention, and Retail Mix Elements between Alfamart and Indomaret in Jakarta, Binus Business Review, Vol. 8, Issue 2), p. 91-97, http://dx.doi.org/10.21512/bbr.v8i2.2066

15. Samson, A. (Ed.) (2020). The Behavioral Economics Guide 2020 (with an Introduction by Colin Camerer), https://www.behavioraleconomics.com

16. Schumann, D.W., Haugtvedt, C.P. and Davidson, E. (2008). History of consumer psychology, chapter 1 of Handbook of consumer psychology, Taylor \& Francis Group/Lawrence Erlbaum Associates, New York

17. Solomon, M.R., Bamossy, G.J., Askegaard, S.T. and Hogg, M.K. (2013). Consumer Behaviour A European Perspective, $5^{\text {th }}$ Edition, Pearson Education Limited. Essex

18. Wintermeier, N. (2019). 46 Psychological Marketing Examples for Smarter Marketing, https:// blog.crobox.com/article/psychological-marketing-examples 